\title{
Feeding, growth, and biochemical studies in very low birthweight infants
}

\author{
S W D'SOUZA, J VALE, D G SIMS, AND M L CHISWICK \\ North Western Regional Perinatal Centre, St Mary's Hospital, Manchester
}

SUMMARY Fifty infants of gestational age 28 to 32 weeks and birthweight less than $1501 \mathrm{~g}$ were reviewed on the expected date of delivery and at conceptional ages of 4, 8, and 12 months. All infants were at home by the expected delivery date, were fed on demand, and weighed regularly. On the expected delivery date and at 4 months, the amounts of formula milk and weaning food accepted were recorded; energy and protein intakes were calculated; and serum sodium, potassium, urea, protein, and osmolality were measured. The birthweight of these infants ranged between the 3rd and 75th centiles (on average about the 20th) but at the expected delivery date was, on average, below the 3rd centile. Infants who had been weaned in the first 4 months after the expected delivery date $(n=26)$ had similar energy and protein intakes and similar biochemical indices to those weaned later $(n=24)$. They achieved catch up growth (below 3rd to 10-25th centile) by 1 year, irrespective of the time of weaning and without any differences in metabolic 'stress'.

It is generally recommended that milk feeds in infants born at term should be supplemented with solids at between 4 and 6 months of age to provide the additional energy and other nutritional requirements in later infancy ${ }^{1-3}$. Early weaning has been associated with increased weight gain, ${ }^{4} 5$ but more recent studies refute this suggestion, ${ }^{6} 7$ while delayed weaning may lead to growth faltering and reduced physical activity. ${ }^{3}$ The relevance of weaning recommendations in term infants has not been seriously considered in preterm infants in spite of the fact that with the availability of intensive care many very preterm infants now survive to be discharged home. ${ }^{8}$ Previous studies have shown that some preterm infants attain growth rates comparable to those of term infants 1 to 2 years after their expected delivery date while others have slower growth rates for longer periods. ${ }^{9-13}$

We report the relation between growth and feeding, and the results of biochemical investigations in very preterm infants after leaving hospital. ${ }^{14}$

\section{Methods}

Preterm infants. A total of 50 singleton infants (23 boys and 27 girls) born at this hospital were studied prospectively. Their birthweights and gestational ages ranged from $840 \mathrm{~g}$ to $1500 \mathrm{~g}$ and 28 to. 32 weeks respectively. Birthweights were distributed between the $2 \cdot 3$ rd and 75 th centiles: ${ }^{15} 18$ birthweights were between the $2 \cdot 3 \mathrm{rd}$ and 10 th centiles, 22 were between the 10th and 25th centiles, nine were between the 25th and 50th centiles, and the remaining one was between the 50th and 75th centiles. All infants were nursed on the Neonatal Medical Unit for 29 to 86 days and suffered a variety of disorders including respiratory distress syndrome, pneumonia, jaundice, sepsis, and necrotising enterocolitis. During their illnesses they were fed intravenously with glucose, electrolytes, amino acids, and lipid. When they recovered they were gavage fed with pooled human milk or formula milk before receiving bottle feeds of formula milk. Their weight gain in hospital ranged from 61 to $178 \mathrm{~g}$ per week. Infants with intraventricular haemorrhage were excluded to avoid any bias on feeding habits caused by later neurological abnormality.

Follow up. Infants were fed on demand at home and reviewed on their expected delivery date (that is, at 40 weeks' gestational age) and at conceptional ages (term plus postnatal age) of 4,8 , and 12 months. They were weighed naked to the nearest $100 \mathrm{~g}$ on a beam balance, and their weights were plotted on centile charts for term infants. ${ }^{16}$ 
Dietary evaluation. Mothers were encouraged to allow the infant to drink formula milk ad libitum, and were not advised about what was a reasonable amount for the infant to take. On the expected delivery date and at age 4 months, mothers made 24 hour records of the volume of formula milk taken at each feed; the type and weight of solid food offered, and the amount rejected; and the volume of milk mixed with solid food. The energy and protein intakes were calculated using information from the food manufacturers' literature. The predicted energy intake in 4 month old term infants and World Health Organisation/Food and Agricultural Organisation recommended energy requirements were obtained from Whitehead et al.$^{17}$ Additional details obtained from each mother included the infant's age when solids were first introduced and the reason for weaning.

Biochemical investigations. On the expected delivery date and at 4 months, venous blood was sampled for measurement of serum sodium, potassium, urea, and protein (auto analyser), and osmolality (freezing point depression).

Statistical methods. Student's $t$ test was used to compare differences between mean values, and the $\chi^{2}$ test was used to compare frequences between groups.

\section{Results}

Forty two mothers made their own decision to wean their infants on to solids, and by far the most common reason was that their infants cried excessively shortly after milk feeds or they were demanding feeds earlier than usual. The other eight mothers sought advice from a doctor, health visitor, nurse, or relative before weaning. Baby rice was the most popular weaning food and was offered as the first solid to 27 infants; 15 infants were first offered rusks; and the remaining eight infants were offered either Liga biscuits, Weetabix, vegetable soup, eggs, semolina, or strained baby food.

Weaning occurred early in 26 infants-that is two weeks to four months from the estimated delivery date: the remaining 24 infants were weaned later at between four and six months. The early weaners and later weaners had similar mean birthweights, birthweight centiles, gestational ages, and duration of stay in hospital. The sex distribution was also similar in the two groups.

Infant growth. The mean weights of boys and girls were below the 3 rd centile at the estimated delivery date but had risen to between the 10th and 25th centiles at 4, 8, and 12 months (Table 1). At each age the mean weights of boys and girls weaned early or later were similar. Nonetheless, individual growth profiles showed considerable diversity. The weights of three infants weaned early and three weaned later did not cross the 3rd centile but progressed below and parallel to it. The weight curves of the remaining infants were distributed between the 3rd and 75 th centiles.

Nutrition. The only type of milk the infants received was formula milk, none received cows' milk or breast feeds. Immediately before weaning infants were being offered five to eight milk feeds daily. Although the early and later weaners had a similar daily volume of milk on the estimated delivery date, at 4 months the milk intake was significantly less in those who had been weaned $(\mathrm{P}<0 \cdot 001)$ (Table 1$)$. Calculated total energy and protein intakes (mean (SD)) at 4 months were similar, however, in those weaned and those receiving only milk. The mean energy intake in the infants at 4 months was 20 to $30 \%$ greater than both the predicted energy intake and the recommended energy requirement for term infants of a comparable age (Table 1). ${ }^{17}$

Biochemical studies. The biochemical indices at the estimated delivery date and at 4 months (mean

Table 1 Infant weight; weight centile; and daily intakes of milk, energy, and protein in preterm infants weaned early (group 1) and late (group 2). (Values, mean (SD))

\begin{tabular}{lll}
\hline & $\begin{array}{l}\text { Group } 1 \\
(n=26)\end{array}$ & $\begin{array}{l}\text { Group } 2 \\
(n=24)\end{array}$ \\
\hline At estimated delivery date & milk only & milk only \\
Infant weight $(\mathrm{g})$ & $2068(219)$ & $2005(183)$ \\
Weight centile & $<3$ rd & $<3$ rd \\
Milk (mV/day) & $382(52)$ & $367(43)$ \\
Protein (g/day) & $5 \cdot 6(0 \cdot 7)$ & $5 \cdot 4(0 \cdot 6)$ \\
Energy (Kcalday) & $248(33)$ & $239(28)$ \\
4 Months later & milk + solid food & milk only \\
Infant weight (g) & $5596(595)$ & $5696(641)$ \\
Weight centile & $10-25$ th & $10-25$ th \\
Milk (ml/day) & $986(184)$ & $1210(183)^{*}$ \\
Protein (g/day) & $17 \cdot 4(2 \cdot 2)$ & $18 \cdot 2(3 \cdot 0)$ \\
Energy (Kcal/day) & $779(85)$ & $791(120)$ \\
Energy/body weight & & \\
(Kcal/kg/day) & & $138 \cdot 8(28 \cdot 6)$ \\
$\quad$ Observed & $139 \cdot 2(25 \cdot 9)$ & $90 \cdot 5$ \\
$\quad$ Predicted $\dagger$ & $90 \cdot 5$ & 115 \\
$\quad$ Recommended & 115 & milk + solid food \\
8 Months later & milk + solid food & $7301(849)$ \\
Infant weight (g) & $7276(847)$ & $10-25$ th \\
Weight centile & $10-25$ th & milk + solid food \\
12 Months later & milk + solid food & $8682(1186)$ \\
Infant weight (g) & $8602(1054)$ & $10-25$ th \\
Weight centile & $10-25$ th & \\
\hline
\end{tabular}

*Level of significance: group $1 v$ group $2, \mathrm{P}<0.001$.

+ Predicted energy intake 120-10.4 (months) +0.76 (months ${ }^{2}$ ); for recommended energy intake (WHO/FAO) see reference 17

Conversion-traditional units to $S I$ : energy $1 \mathrm{Kcal} / \mathrm{day} \approx 0.004 \mathrm{MJ} / \mathrm{day}$. 
Table 2 Serum concentrations of sodium, potassium, urea, protein and osmolality in preterm infants weaned early (group 1) and late (group 2). (Values, mean $(S D))$

\begin{tabular}{lll}
\hline & $\begin{array}{l}\text { Group I } \\
(n=26)\end{array}$ & $\begin{array}{l}\text { Group } 2 \\
(n=24)\end{array}$ \\
\hline At estimated delivery date & milk only & milk only \\
Sodium $(\mathrm{mmol}(\mathrm{mEq}) / \mathrm{l})$ & $138 \cdot 7(2 \cdot 1)$ & $139 \cdot 2(1 \cdot 9)$ \\
Potassium $(\mathrm{mmol}(\mathrm{mEq}) / 1)$ & $5 \cdot 1(0 \cdot 2)$ & $4 \cdot 6(0 \cdot 6)$ \\
Urea $(\mathrm{mmol} / \mathrm{l})$ & $1 \cdot 8(0 \cdot 2)$ & $1 \cdot 6(0 \cdot 3)$ \\
Protein $(\mathrm{g} / \mathrm{l})$ & $43 \cdot 7(4 \cdot 9)$ & $42 \cdot 2(6 \cdot 1)$ \\
Osmolality $(\mathrm{mOsm} / \mathrm{kg})$ & $279 \cdot 5(2 \cdot 6)$ & $280 \cdot 5(2 \cdot 3)$ \\
4 months later & milk $+\mathrm{solid}$ food & milk only \\
Sodium $(\mathrm{mmol}(\mathrm{mEq}) / \mathrm{l})$ & $138 \cdot 0(3 \cdot 9)$ & $138 \cdot 1(3 \cdot 1)$ \\
Potassium $(\mathrm{mmol}(\mathrm{mEq}) / 1)$ & $4 \cdot 9(0 \cdot 6)$ & $5 \cdot 2(0 \cdot 7)$ \\
Urea $(\mathrm{mmol} / \mathrm{l})$ & $2 \cdot 6(0 \cdot 4)^{*}$ & $2 \cdot 5(0 \cdot 7)^{*}$ \\
Protein $(\mathrm{g} / \mathrm{l})$ & $60 \cdot 0(5 \cdot 4)^{*}$ & $59 \cdot 2(4 \cdot 3)^{*}$ \\
Osmolality $(\mathrm{mOsm} / \mathrm{kg})$ & $280 \cdot 0(4 \cdot 1)$ & $282 \cdot 8(3 \cdot 1)$ \\
\hline
\end{tabular}

Group $1 v$ group 2: no significant differences in sodium, potassium, urea, protein, and osmolality.

Estimated delivery date $v 4$ months later: ${ }^{*} \mathrm{P}<0.001$

Conversion-SI to traditional units: urea $1 \mathrm{mmol} / \approx 00 \cdot 006 \mathrm{~g} / \mathrm{ml}$.

(SD)) were similar in the early and later weaners (Table 2). The only values that had risen between the estimated delivery date and 4 months were the serum urea and protein concentrations.

\section{Discussion}

The first 4 months after the estimated delivery date was a period of relatively rapid growth in our preterm infants-probably an attempt at catch up growth, to recover previous deficits. ${ }^{18}$ Their weights at birth were on average about the 20th centile and on the estimated delivery date, on average, below the 3rd centile. Improvement in growth rate was associated with a considerable drive to feed. Whether the infants were receiving solely milk or milk and solids their energy intake in relation to body weight (Kcal/ $/ \mathrm{kg} /$ day) exceeded previously reported energy intakes which satisfy the needs of term infants of a comparable postnatal age. This observation is to some extent analogous to that previously reported in small for dates infants ${ }^{19}$ and infants recovering from protein-calorie malnutrition, ${ }^{20}$ who increase their energy intakes to levels considerably higher than their normal requirements to recover growth deficits.

Our study suggests that in rapidly growing preterm infants extra energy requirements can be obtained from milk alone provided milk intake is substantially increased. The mean milk intake per day in our infants fed solely on milk was about $15 \%$ more than the average milk intake reported for 4 month old breast fed infants born at term, and growing along the 95 th centile. ${ }^{21}$ In addition, milk intake per day was about $25 \%$ more than the average formula milk intake reported for infants of similar weight but born at term. ${ }^{22}$ In the early weaners solid food tended to replace rather than supplement formula milk in the diet. Accordingly, energy intake was not affected appreciably by the early introduction of solids. In that respect our observations are similar to those previously reported in term infants who seem capable of regulating food intake on an energy basis when over 6 weeks of age. ${ }^{23} 24$

Relatively large intakes of formula milk and the early introduction of rice or rusks did not have a significant effect on serum sodium, potassium, and osmolality values in our preterm infants. The rise in serum urea and protein concentrations observed 4 months after the estimated delivery date was probably a reflection of an increase in dietary protein intake. Despite this increase the urea concentrations are similar to those previously reported in breast fed infants. ${ }^{25}$ It seems that modern formula milk given to our infants is not likely to cause plasma hyperosmolality (greater than $300 \mathrm{mmol} / \mathrm{kg}$ ) ${ }^{14}$ and raised urea concentrations ${ }^{26}$ previously reported in infants receiving a formula based on whole cows' milk.

Recommendations for weaning commonly used for feeding term infants may also be applied to preterm ones after the expected delivery date-we found that earlier weaning did not improve catch up growth. The Department of Health and Social Security report on infant feeding in $1980^{27}$ is slightly different in its weaning recommendations to the 1974 report: $^{1}$ recommendations are from 3 to 6 months and generally more permissive. Since the timing does not seem critical in terms of growth rate, an approach to weaning which takes into account the mother's assessment of her infant's needs is more realistic than one that is based only on a predetermined age.

The authors thank the mothers who participated in this study, the health visitors who did home visits and supervised infant feeding, the Biochemistry Department where the blood specimens were analysed, Professor RDH Boyd for helpful criticism, and Mrs Elaine Evans for secretarial assistance.

\footnotetext{
References

1 Department of Health and Social Security. Present day practice in infant feeding. Report on Health and Social Subjects, no. 9. London: HMSO, 1974.

2 American Academy of Pediatrics Committee on Nutrition. On the feeding of supplemental food to infants. Pediatrics 1980;65: 1178-81.

3 Underwood BA, Hofvander Y. Appropriate timing for complementary feeding of the breast-fed infant. Acta Paediatr Scand 1982; Suppl 294:1-32.

4 Taitz LS, Byers HD. High calorie/osmolar feeding and hypertonic dehydration. Arch Dis Child 1972;47:257-60.
} 
5 Shukla A, Forsyth HA, Anderson CM, Marwah SM. Infantile overnutrition in the first year of life: a field study in Dudley, Worcestershire. Br Med J 1972;iv:507-14.

${ }^{6}$ de Swiet M, Fayers P, Cooper L. Effect of feeding habit on weight gain in infancy. Lancet $1977 ; \mathbf{i}: 892-4$.

7 Wilkinson PW, Davies DP. When and why are babies weaned? Br Med J 1978;i:1682-3.

${ }^{8}$ Stewart AL, Reynolds EOR, Lipscomb AP. Outcome for infants of very low birthweight: survey of world literature. Lancet 1981;i:1038-41.

9 Babson G. Growth of low-birth-weight infants. J Pediatr 1970;77:11-8.

${ }^{10}$ Cruise MO. A longitudinal study of the growth of low birthweight infants. 1. Velocity and distance growth, birth to 3 years. Pediatrics 1973;51:620-8.

1 Fitzhardinge PM. Early growth and development in low birthweight infants following treatment in an intensive care nursery. Pediatrics 1975;56:162-72.

12 Kitchen WH, McDougall AB, Naylor FD. A longitudinal study of very-low-birth-weight infants. 111. Distance growth at eight years of age. Dev Med Child Neurol 1980;22:163-88.

13 Kimble KJ, Ariagno RL, Stevenson DK, Sunshine P. Growth to age 3 years among very low-birth-weight sequelae-free survivors of modern neonatal intensive care. J Pediatr 1982;100:622-4.

14 Davies DP. Plasma osmolality and feeding practices of healthy infants. $\mathrm{Br}$ Med J 1973;ii:340-2.

15 Milner RDG, Richards B. An analysis of birthweight by gestational age of infants born in England and Wales: 1967 to 1971. Journal of Obstetrics and Gynaecology of the British Commonwealth 1974;81:956-67.

16 Tanner JM, Whitehouse RH. Standards for height and weight of British children from birth to maturity. Lancet 1959;ii:1086-8.

17 Whitehead RG, Paul AA, Cole TJ. How much breast milk do babies need? Acta Paediatr Scand 1982;Suppl 299:43-50.
${ }^{18}$ Fomon SJ, Zeigler EE, Vasquez HD. Human milk and the small premature infant. Am J Dis Child 1977;131:463-7.

19 Davies DP. Some aspects of 'catch-up' growth in 'light-for-dates' babies. In: Wharton B, ed. Topics in paediatrics 2: Nutrition in childhood. London: Royal College of Physicians of London and Pitman Medical, 1980:72-80.

20) Brooke OG, Wheeler EF. High energy feeding in protein energy malnutrition. Arch Dis Child 1976;51:968-71.

21 Whitehead RG, Paul AA. Infant growth and human milk requirement. Lancet 1981;ii:161-3.

22 Fomon SJ, Owen GM, Thomas LN. Milk or formula volume ingested by infants fed ad libitum. Am J Dis Child 1964;108: 601-4.

${ }^{23}$ Guthrie HA. Effect of early feeding of solid food on nutritive intake of infants. Pediatrics 1966:38:879-85.

${ }^{24}$ Marlin DW, Picciano MF, Livant EC. Infant feeding practices. J Am Diet Assoc 1980;77:668-76.

${ }^{25}$ Dale G, Goldfinch ME, Sibert JR, Webb JKG. Plasma osmolality, sodium, and urea in healthy breast-fed and bottlefed infants in Newcastle-upon-Tyne. Arch Dis Child 1975; 50:731-4.

26 Davies DP, Saunders R. Blood urea. Normal values in early infancy related to feeding practices. Arch Dis Child 1973;48: $563-5$.

27 Department of Health and Social Security. Present day practice in infant feeding: 1980. Report on Health and Social Subjects, no 20. London: HMSO, 1980.

Correspondence to Dr S W D'Souza, Department of Child Health, St Mary's Hospital, Manchester M13 0JH.

Received 7 December 1984 